DOES THE

NEW YORK

CONSTITUTION

PROHIBIT DAILY

FANTASY SPORTS?

TWO NEW YORK

COURTS SAY SO,

BUT THE NEW YORK

COURT OF APPEALS

WILL SOON DECIDE

ONCE AND FOR ALL

\section{ROB ROSBOROUGH}

Rob Rosborough is a partner at Whiteman Osterman \& Hanna LLP in Albany, New York, USA. His practice focuses on appellate litigation in the New York state and federal courts. He has closely followed the White v. Cuomo challenge to the constitutionality of daily fantasy sports since the case's inception on his blog, New York Appeals. He can also be found on Twitter.

I t's a sunny fall Sunday morning in upstate New York, and you're looking forward to a full slate of football games. You've consumed all the news reports that Adam Schefter and Ian Rapoport have put out on Twitter, formulated potential daily fantasy football lineups within the salary cap, and you're waiting for the teams' 11:30 a.m. injury decisions. You open your daily fantasy sports
(DFS) app of choice and work on finalizing your lineup. You've decided to pay up for a stud running back, while relying on a bargain basement quarterback stacked with an up and coming, exciting wideout with a great matchup. You've made your decision. You lock your lineup, and watch to see what happens. Will your team outperform all the others and win the prize? The games will decide.

To two New York courts, however, you've violated the New York Constitution because DFS is prohibited gambling. New York is different. Gambling isn't just prohibited by statute that can be easily amended by the legislature. It is banned by the text of the state constitution itself. ${ }^{1}$ And when a group of plaintiffs challenged New York's 2016 Interactive Fantasy Sports (IFS) law that authorized DFS in New York for the first time, the courts held that the law violates the constitutional ban because DFS contests involve a material degree of chance. The State has appealed the rulings to New York's highest appellate court, the New York Court of Appeals. May DFS continue in New York uninterrupted under the 2016 IFS law, or must the New York Constitution be amended to permit the games in the state? The Court of Appeals will soon decide the fate of DFS in New York once and for all.

This article examines New York's constitutional ban on gambling, looks at the courts' rationale for declaring DFS unconstitutional, and finally explains how I think the Court of Appeals should view the issues.

\section{THE NEW YORK CONSTITUTIONAL BAN ON GAMBLING}

Article I, $\S 9$ of the New York Constitution provides that "no lottery or the sale of lottery tickets, pool-selling, book-making, or any other kind of gambling, except [the state lottery, pari-mutuel wagering, and casino gambling] shall hereafter be authorized or allowed within this state." ${ }^{2}$ Article I, $\S 9$ is a broad ban
Keywords: daily fantasy sports, gambling, New York Constitution

DOI: $10.1089 / \mathrm{glr} 2.2020 .0002$ (C) 2020 Mary Ann Liebert, Inc.

${ }^{1}$ General state constitutional bans on gambling can be found in a number of states throughout the country. See. e.g., IDAHO CONST. art. III, § 20; MI. ConsT. art. 4, § 41 ("No law enacted after January 1, 2004, that authorizes any form of gambling shall be effective, nor after January 1, 2004, shall any new state lottery games utilizing table games or player operated mechanical or electronic devices be established, without the approval of a majority of electors voting in a statewide general election and a majority of electors voting in the township or city where gambling will take place."); N.J. ConsT. art. 4, § 7, 2 ("No gambling of any kind shall be authorized by the Legislature unless the specific kind, restrictions and control thereof have been heretofore submitted to, and authorized by a majority of the votes cast by, the people at a special election or shall hereafter be submitted to, and authorized by a majority of the votes cast thereon by, the legally qualified voters of the State voting at a general election")

${ }^{2}$ N.Y. Const. art. I, $\S 9$ (emphasis added). 
on gambling that has been construed by the New York courts to prohibit many different types of games, ${ }^{3}$ unless they have been specifically exempted through a constitutional amendment. ${ }^{4}$

Although the New York Constitution doesn't define the term "gambling," New York's criminal code does. That definition is what the courts have looked at to decide the scope of prohibited gambling under the constitution. "Gambling" is defined as risking something of value (e.g., money) "upon the outcome of a contest of chance or a future contingent event not under his control or influence, upon an agreement or understanding that he will receive something of value in the event of a certain outcome." "G Getting a little further into the weeds, a "contest of chance" is then in turn defined as "any contest, game, gaming scheme or gaming device in which the outcome depends in a material degree upon an element of chance, notwithstanding that skill of the contestants may also be a factor therein."7

Breaking it down, gambling in New York has been defined as a game where a player risks money (or something else of value) on the outcome of an event that he or she doesn't control and that depends upon a "material" degree of chance, even if some skill is required to win. ${ }^{8}$ And in the beginning, New York Attorney General Eric Schneiderman brought a high profile suit to enjoin the New York operations of Draft Kings and FanDuel, arguing that their DFS games violated New York's constitutional ban on gambling. ${ }^{9}$

\section{THE 2016 INTERACTIVE FANTASY SPORTS LAW AND WHITE V. CUOMO}

In addition to opposing the attorney general's lawsuit, Draft Kings, FanDuel, and the entire DFS industry undertook a substantial lobbying effort to legalize
DFS in New York. Instead of pushing for a constitutional amendment to create an exception for DFS from the ban on "gambling," like the legislature has done before for the state lottery, horseracing, and most recently to allow casinos, ${ }^{10}$ however, the industry decided to try a shorter path. In New York, a constitutional amendment is, at minimum, a two-plus-year process. ${ }^{11}$ The proposed amendment must be passed in two successive legislative sessions and then approved at a referendum by the people of the state at a general election. ${ }^{12}$ The DFS industry didn't want to wait that long. So, the industry pushed for a one-off bill instead.

In 2016, the New York Legislature passed Chapter 237 of the Laws of 2016, which tried to exempt "interactive fantasy sports" from the constitutional ban by including legislative findings that DFS is not gambling:

1. The legislature hereby finds and declares that:

(a) Interactive fantasy sports are not games of chance because they consist of fantasy or simulation sports games or contests in which the fantasy or simulation sports teams are selected based upon the skill and knowledge of the participants and not based on the current membership of an actual team that is a member of an amateur or professional sports organization;

(b) Interactive fantasy sports contests are not wagers on future contingent events not under the contestants' control or influence because contestants have control over which players they choose and the outcome of each contest is not dependent upon the performance of any one player or any one actual team. The outcome of any fantasy sports contest does not correspond to the outcome of any one sporting event.

\footnotetext{
${ }^{3}$ See, e.g., Plato's Cave Corp. v. State Liq. Auth., 68 N.Y.2d 791, $793-94$ (N.Y. 1986); People v. Turner, 165 Misc.2d 222, 223-24 (N.Y. Crim. Ct. 1995) (“Games of chance range from those that require no skill, such as a lottery, to those such as poker or blackjack which require considerable skill in calculating the probability of drawing particular cards. Nonetheless, the latter are as much games of chance as the former, since the outcome depends to a material degree upon the random distribution of cards. The skill of the player may increase the odds in the player's favor, but cannot determine the outcome regardless of the degree of skill employed." [citations omitted]); but see, e.g., People v. Mohammed, 187 Misc.2d 729, 732-33 (N.Y. Crim. Ct. 2001) (three-card monte is a game of skill, not prohibited gambling).

${ }^{4}$ N.Y. Const. art. I, $\S 9$ (exempting the state lottery, "pari-mutuel betting on horse races," and casino gaming from the constitutional ban on gambling).

${ }^{5} I d$.
}

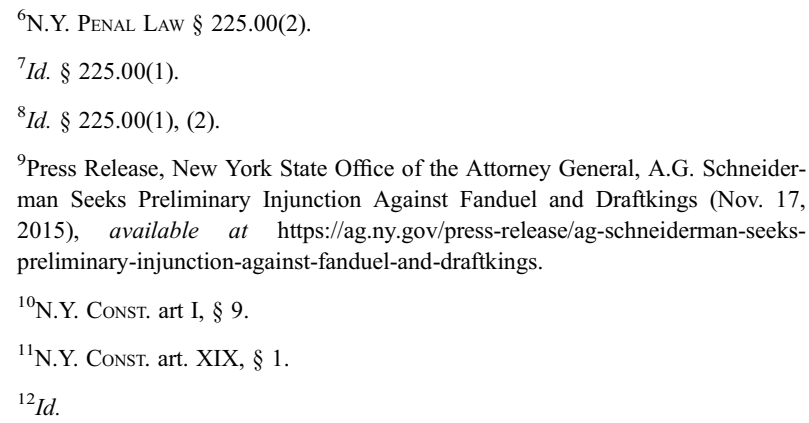
man Seeks Preliminary Injunction Against Fanduel and Draftkings (Nov. 17, 2015), available at https://ag.ny.gov/press-release/ag-schneiderman-seekspreliminary-injunction-against-fanduel-and-draftkings.

${ }^{10}$ N.Y. CONST. art I, $\S 9$.

${ }^{11}$ N.Y. Const. art. XIX, $\S 1$

${ }^{12} I d$. 
Instead, the outcome depends on how the performances of participants' fantasy roster choices compare to the performance of others' roster choices.

2. Based on the findings in subdivision one of this section, the legislature declares that interactive fantasy sports do not constitute gambling in New York state as defined in article two hundred twenty-five of the penal law. ${ }^{13}$

After the legislature passed the Interactive Fantasy Sports Law legalizing DFS in New York in 2016, the attorney general settled the case against FanDuel and DraftKings and found itself in the unenviable position of having to switch sides to defend the new enactment. ${ }^{14}$

Unsurprisingly, a group of plaintiffs challenged the new IFS law in the New York trial courts, arguing that DFS is gambling prohibited by the New York Constitution, the very same argument that the attorney general had just made in the DraftKings and FanDuel suit. ${ }^{15}$ In support of their position, the plaintiffs argued that the constitution does not give the legislature the power to create exceptions to the ban on gambling without following the constitutional amendment process. ${ }^{16}$ Indeed, they noted, the legislature has authorized four exceptions to the constitutional ban by amendment: betting on horseracing, games of chance like bingo and lottery run by non-profits, state-run lotteries, and the casinos. ${ }^{17}$ The legislature has not amended the constitution to permit DFS, and can't do so merely by legislation. ${ }^{18}$ As the plaintiffs put it:

In enacting [the IFS law], the Legislature has done exactly the opposite of what Article I, $\S 9$ of the Constitution commands. Instead of passing laws to prevent gambling, it has enabled it. It has also provided a tortured interpretation of the term "gambling" that defies its ordinary meaning while violating the principle that exceptions to constitutional prohibitions should be strictly construed. ${ }^{19}$

Under New York law, "[1]egislative enactments enjoy a strong presumption of constitutionality and parties challenging a duly enacted statute face the initial burden of demonstrating the statute's invalidity beyond a reasonable doubt. ${ }^{20}$ Indeed, a facial constitutional challenge must establish that "in any degree and in every conceivable application, the law suffers wholesale constitutional impairment." 21 That's a heavy burden for the plaintiffs to carry.

The State countered that the legislature had been granted the authority to enforce the constitutional gambling ban, which included the power to define DFS as outside of that prohibition. ${ }^{22}$ Thus, the State argued that the legislature's enactment was rational, and the plaintiffs failed to establish its unconstitutionality beyond a reasonable doubt. ${ }^{23}$

\section{NEW YORK TRIAL COURT JUDGE DECLARES IFS LAW UNCONSTITUTIONAL IN PART}

In a seemingly split decision, Judge Gerald Connolly of the New York trial court agreed with the plaintiffs, holding that the scope of the term "gambling" in the New York Constitution must be construed broadly

\footnotetext{
${ }^{13}$ N.Y. Rac. Pari-Mut. WaG. and BreEd. LaW $§ 1400(1)$, (2).

${ }^{14}$ Press Release, New York State Office of the Attorney General, A.G. Schneiderman Announces \$12 Million Settlement with Draftkings and Fanduel (Oct 25, 2016), available at https://ag.ny.gov/press-release/2016/ag-schneidermanannounces-12-million-settlement-draftkings-and-fanduel (last accessed Mar. 7, 2020).

${ }^{15}$ Dustin Gouker, Anti-Gambling Group Leads Lawsuit Against New York Daily Fantasy Sports Law, Legal SpORTs Report (Oct. 5, 2016), available at https://www. legalsportsreport.com/11750/new-york-dfs-lawsuit/ (last accessed Mar. 7, 2020).

${ }^{16}$ Plaintiffs' Memorandum of Law in Support of Summary Judgment at 22-23, White v. Cuomo, Index No. 5861-2016 (NY. Sup. Ct. Albany Cty. 2018), available at https://nysappeal.files.wordpress.com/2018/01/white-v-cuomo-plaintiffsmemorandum-of-law-1-29-18.pdf (last accessed Mar. 7, 2020).

${ }^{17} I d$. at 23 .

${ }^{18} I d$.

${ }^{19} I d$. at 25 .
}

\footnotetext{
${ }^{20}$ Overstock.com, Inc. v. New York State Dept. of Taxation \& Fin., 20 N.Y.3d 586, 593 (N.Y. 2013) (cleaned up), cert. denied 571 U.S. 1071 (2013).

${ }^{21}$ Cohen v. State of New York, 94 N.Y.2d 1, 8 (N.Y. 1999) (internal quotation marks omitted)

${ }^{22}$ The State moved to dismiss the suit, arguing that the legislature has been granted the authority to enforce the constitutional gambling prohibition, which included the power to define daily fantasy sports (DFS) as outside of that prohibition. The trial court held that that argument was better suited for a summary judgment motion, not one for dismissal on the pleadings, and denied the State's motion. See White v. Cuomo, Index No. 5861-2016 (N.Y. Sup. Ct. Albany Cty. Aug. 31, 2017), at 5, available at https://nysappeal.files.wordpress.com/2017/09/white-v-nys-decisionorder-8-31-17.pdf (last accessed Mar. 7, 2020)

${ }^{23}$ State's Memorandum of Law in Opposition to Plaintiff's Motion for Summary Judgment and in Support of Cross Motion for Summary Judgment at 11-26, White v. Cuomo, Index No. 5861-2016 (N.Y. Sup. Ct. Albany Cty. Mar. 9, 2018), available at https://nysappeal.files.wordpress.com/2018/12/state-memorandumof-law-in-opposition-to-summary-judgment.pdf (last accessed Mar. 7, 2020).
} 
according to its plain meaning. ${ }^{24}$ The terms are broad and all-inclusive, the trial court noted. ${ }^{25}$ The "any other form of gambling" language in the constitutional ban requires an "expansive, not a limited" interpretation. ${ }^{26}$ Indeed, the trial court noted, it has been interpreted previously by the New York attorney general to forbid sports gambling, which includes DFS. ${ }^{27}$ The trial court thus held that DFS, which involves the selection of players over whom the DFS participants have no control after the lineups are set, is gambling and falls within New York's constitutional ban. $^{28}$

It is not for the legislature to define the scope of the constitutional ban, the trial court held. ${ }^{29}$ Accepting the State's interpretation would allow the legislature's definition of gambling in a statute to render the constitutional provision meaningless, a construction that must be avoided under normal principles of constitutional interpretation. ${ }^{30}$ A statute cannot change the effect of a constitutional provision. ${ }^{31}$ To change the constitution, the amendment process must be followed. And the legislature did not do that here for DFS.

The trial court also rejected the State's argument that because DFS involves a measure of skill, a fact which the court presumed to be true, it can't be a game of chance prohibited by the constitution. ${ }^{32}$ The drafters of the constitutional ban on gambling intended to prohibit "contests based on future contingent events," which DFS clearly is, the trial court reasoned, regardless of the skill involved. ${ }^{33}$

Although the trial court largely sided with the plaintiffs' argument that DFS is prohibited by the New
York constitutional ban on gambling, it did reject one portion. In a confusing distinction, the trial court held that the legislature's decriminalization of DFS was not unconstitutional. ${ }^{34}$ The trial court held that it was not within its scope of judicial review to declare that the legislature could not define DFS as outside of the statutory definition of gambling. ${ }^{35}$ That decision, the trial court reasoned, lies entirely with the legislature. ${ }^{36}$

The State appealed the trial court's order, and the plaintiffs cross-appealed the portion that upheld the legislature's decision to decriminalize DFS. ${ }^{37}$ Under the New York Civil Practice Law and Rules, the State's appeal automatically stayed enforcement of the trial court's order, ${ }^{38}$ which meant that DFS could continue to be offered in New York while the appeals are ongoing. That alone had to be some solace to the DFS industry, which is raking in hundreds of millions of dollars in revenue annually. ${ }^{39}$

\section{THE NEW YORK APPELLATE DIVISION DECLARES THE IFS LAW UNCONSTITUTIONAL IN ITS ENTIRETY}

\section{A. The parties' arguments}

In its opening brief challenging the trial court's holding that the IFS law is unconstitutional, the State argued that because the constitution leaves the term "gambling" undefined, and specifically authorizes the legislature to implement the constitutional ban, it has to be up to the legislature to fill the gap by defining what is and what isn't prohibited gambling. ${ }^{40}$ Specifically, the State built its case on traditional

\footnotetext{
${ }^{24}$ White v. Cuomo, 62 Misc.3d 877, 890 (N.Y. Sup. Ct. 2018).

${ }^{25} I d$. at 893 .

${ }^{26} I d$.

${ }^{27} I d$. at 891 .

${ }^{28} I d$. at $895-97$.

${ }^{29} I d$. at 896 .

${ }^{30} I d$. at $896-97$.

${ }^{31} I d$. at 895 .

${ }^{32} I d$. at 896 .

${ }^{33} I d$. at 894,896 .

${ }^{34} I d$. at 898 .

${ }^{35} I d$.

${ }^{36} I d$.
}

\footnotetext{
${ }^{37}$ See State's Notice of Appeal, White v. Cuomo, Index No. 5861-2016 (N.Y. Sup. Ct., Albany Cty. Nov. 28, 2018), available at https://nysappeal.files.wordpress. com/2018/12/State-Notice-of-Appeal.pdf (last accessed Mar. 7, 2020); Plaintiffs' Notice of Cross Appeal, White v. Cuomo, Index No. 5861-2016 (N.Y. Sup. Ct., Albany Cty. Nov. 30, 2018), available at https://nysappeal.files.wordpress.com/ 2018/12/Plaintiffs-Notice-of-Cross-Appeal.pdf (last accessed Mar. 7, 2020).

${ }^{38}$ See N.Y. C.P.L.R. 5519(a)(1).

${ }^{39}$ See Katie Callahan, DFS Revenue Growth Appears to be Stalling, PLAY USA (July 5, 2018), available at https://www.playusa.com/dfs-generates-335mrevenue/ (last accessed Mar. 2, 2020); Dustin Gouker, New Official Data: Daily Fantasy Sports Generated \$335 Million in Revenue in a Year, LEGAL SPORTS REPORT (June 28, 2018), available at https://www.legalsportsreport.com/21627/ny-dfs/ (last accessed Mar. 2, 2020).

${ }^{40}$ State's Opening Brief at 21-23, White v. Cuomo, Docket No. 528026 (N.Y. Sup Ct., App. Div., 3d Dept., Mar. 8, 2019), available at https://nysappeal.files. wordpress.com/2019/04/states-corrected-app-div-opening-brief.pdf (last accessed Mar. 9, 2020).
} 
notions of judicial deference to rational legislative decision making. ${ }^{41}$ The State points out that the New York Court of Appeals-New York's high court - has repeatedly held that where the constitution provides broad and undefined powers to the legislature to implement a constitutional provision, as here, the courts must defer to the legislature's factual findings and rational implementations of that power. ${ }^{42}$

Here, the State argued, Article I, $\S 9$ of the New York Constitution bans "gambling," but expressly delegates to the legislature to pass laws that carry out that command. ${ }^{43}$ Because the legislature has outlined what prohibited "gambling" looks like in New York's criminal statutes, and undertook an extensive fact-finding process to determine that DFS does not fall within that definition, the State argued that it's not for the courts to undermine the legislature's rational conclusion that DFS games are not prohibited gambling. ${ }^{44}$ As the IFS law specifically found, they are not games of pure chance, but are instead based on a player's skill in assembling a roster of real-life athletes to compete against everyone else's chosen rosters. ${ }^{45}$ DFS games, therefore, are not predominately contingent upon games outside of the player's control, but on his or her player selection and roster management abilities. ${ }^{46}$

In the plaintiffs' opening brief to the Appellate Division, they made four principal arguments for an affirmance of the trial court's decision declaring the IFS law unconstitutional: (1) DFS falls within the Penal Law's definition of prohibited gambling, and the legislature's rationale for an opposite finding ignores the realities that DFS is a game involving a material degree of chance and are wagers on future contingent events; (2) the New York attorney general admitted that DFS is prohibited gambling when it prosecuted DraftKings and FanDuel before the IFS law was adopted; (3) DFS looks like gambling and is regulated like gambling, so it must be gambling; and (4) the legislature was not free to define gambling to exclude DFS because it had applied the constitutional gambling ban to all forms of sports wagering over more than 100 years. $^{47}$

Plaintiffs argued on their cross appeal that the trial court also should have declared unconstitutional the legislature's attempt to decriminalize DFS without substituting some other penalty. ${ }^{48}$ As the plaintiffs viewed the constitutional commands, Article I, $\S 9$ required the state to pass laws to prevent gambling. ${ }^{49}$ The removal of the criminal sanction in the IFS law is permitted, therefore, only if the legislature substituted some other penalty in its place. ${ }^{50}$ "It could, for example, have enacted a civil law prohibiting gambling and imposing civil fines to prevent any person or entity from operating IFS. Instead, it left a statutory and regulatory vacuum by decriminalizing gambling while not substituting something else in its place to prevent it." ${ }^{, 51}$ This legal limbo, where DFS has been decriminalized but still violates the constitutional ban, cannot withstand scrutiny, the plaintiffs argued..$^{52}$ Either the IFS law falls in its entirety, or it doesn't. ${ }^{53}$

\section{B. The amici}

The State and the plaintiffs weren't the only ones who wanted to be heard on whether the New York IFS law violates New York's constitutional ban on gambling. New York courts generally encourage amicus submissions, and three parties sought to file amici briefs expressing their views on the issuesFanDuel and DraftKings in support of the State, ${ }^{54}$

\footnotetext{
${ }^{41} I d$. at $21-22$.

${ }^{42} I d$. at $22-26$.

${ }^{43} I d$. at 21 .

${ }^{44} I d$. at $26-28$.

${ }^{45}$ Id. at $34-38$.

${ }^{46} I d$.

${ }^{47}$ See generally Plaintiffs' Opening Brief at 29-68, White v. Cuomo, Docket No 528026 (N.Y. Sup. Ct., App. Div., 3d Dept., Apr. 9, 2019), available at https:// nysappeal.files.wordpress.com/2019/05/opening-brief-for-respondents-crossappellants-o0388227xd07f1.pdf (last accessed Mar. 9, 2020).
}

\footnotetext{
${ }^{48}$ See id. at $69-75$.

${ }^{49}$ See id. at $69-70$.

${ }^{50} I d$. at 70

${ }^{51} I d$.

${ }^{52}$ See id. at $71-72$.

${ }^{53} I d$. at 72 .

${ }^{54}$ Notice of Motion and Amicus Brief on Behalf of FanDuel, Inc. and DraftKings, Inc., White v. Cuomo, Docket No. 528026 (N.Y. Sup. Ct., App. Div., 3d Dept., Apr. 30, 2019), available at https://nysappeal.files.wordpress.com/2019/07/ fandueldraftkings-amicus-motion-brief.pdf (last accessed Mar. 9, 2020).
} 
and Rivers Casino, one of New York's four licensed brick-and-mortar casinos, in support of the plaintiffs. ${ }^{55}$

FanDuel's and DraftKings' arguments were remarkably similar to the State's arguments in its opening brief. They both argued that DFS is not gambling prohibited by the New York Constitution because the skill required dominates chance-based elements. ${ }^{56}$ Thus, it is a bona fide contest for a prize, which is not gambling, they argued. ${ }^{57}$ What distinguishes FanDuel's and DraftKings' arguments from the State's is the legal test that they each argued should apply. While the State sought to have the Appellate Division apply the "dominating element" test that holds that a game constitutes prohibited gambling when chance dominates any skill involved rather than the "material degree" test that holds a game is gambling when the outcome depends upon chance in a material respect, which the trial court applied to hold the IFS law unconstitutional, FanDuel and DraftKings argued that the tests are substantively identical. ${ }^{58}$ It's just that the trial court got it wrong under both.

On the other side, Rivers Casino sought to appear in support of the plaintiffs' arguments that the IFS law is unconstitutional, arguing that the law had fundamentally upset the casino gambling industry's legitimate expectations that gambling can only be authorized in New York by a constitutional amendment. ${ }^{59}$ That's what the casinos had to do, and so too should the fantasy sports industry, it argued.

Beyond the "we had to get a constitutional amendment, and so should you" rhetoric, Rivers Casino's legal argument was fairly straightforward. It offered a definition of constitutionally prohibited gambling that was far stricter than any party to the case had previously discussed and didn't rely at all on the skill versus chance dichotomy. ${ }^{60}$ As Rivers Casino put it,

Before considering the meaning and scope of the Penal Law, this Court first must decide if DFS constitutes gambling as that term is used in the Constitution. For reasons explained below, the term gambling as used in the Constitution means simply: to wager on games of skill or chance. Whether DFS is viewed as a game of skill or chance, or should be subject to criminal penalties in New York, it is still unauthorized "gambling" as that term is used in the Constitution. From there, the Legislature presumably may decide to criminalize DFS, or to prescribe civil penalties, but the Legislature cannot somehow "authorize" DFS. Chapter 237, therefore violates the Constitution's general prohibition against gambling. ${ }^{61}$

Rivers Casino's arguments, however, were never considered by the Third Department because the court denied its request to file the amicus brief. ${ }^{62}$ Although the court did not give an express reason for its decision, and the Appellate Division's rules don't contain an express requirement for a proposed amicus party to disclose their financial stake in the case or whether a party is backing or funding the amicus submission, whether an amicus party is a true friend of the court, rather than a party with a direct financial interest in the outcome of the case, is certainly something that the court can, and often does, consider. ${ }^{63}$ The court may have been concerned that Rivers Casino's interest was a purely economic concern about competition to its brick-and-mortar casino, and wasn't a true friend seeking to assist the court with its decision.

\footnotetext{
${ }^{55}$ Notice of Motion and Amicus Brief on Behalf of Capital Region Gaming, LLC d/ b/a Rivers Casino Schenectady, White v. Cuomo, Docket No. 528026 (N.Y. Sup. Ct., App. Div., 3d Dept., Jun. 28, 2019), available at https://nysappeal.files. wordpress.com/2019/07/amicus-motion-and-proposed-brief-of-rivers-casino.pdf (last accessed Mar. 9, 2020).

${ }^{56}$ Amicus Brief on Behalf of FanDuel, Inc. and DraftKings, Inc., supra note 54, at $8-11$.

${ }^{57} I d$. at 11

${ }^{58}$ See id. at $16-20$.

${ }^{59}$ Amicus Brief on Behalf of Capital Region Gaming, LLC d/b/a Rivers Casino Schenectady, supra note 55, at 1-2.

${ }^{60}$ See id. at 6-8.
}

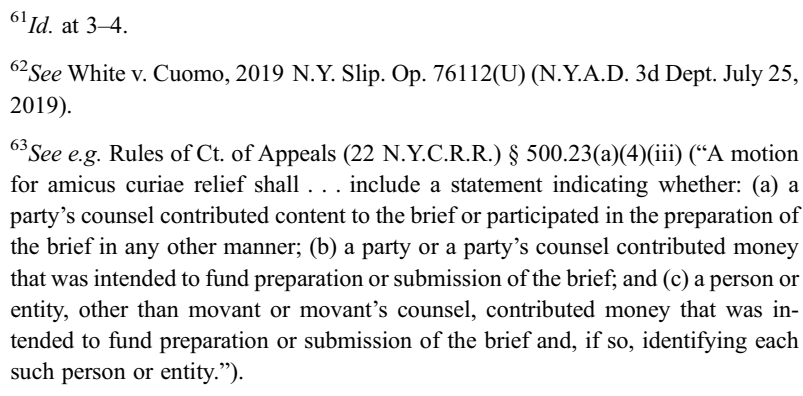
2019).

${ }^{63}$ See e.g. Rules of Ct. of Appeals (22 N.Y.C.R.R.) § 500.23(a)(4)(iii) (“A motion for amicus curiae relief shall . . include a statement indicating whether: (a) a party's counsel contributed content to the brief or participated in the preparation of the brief in any other manner; (b) a party or a party's counsel contributed money that was intended to fund preparation or submission of the brief; and (c) a person or entity, other than movant or movant's counsel, contributed money that was intended to fund preparation or submission of the brief and, if so, identifying each such person or entity."). 


\section{The Appellate Division's opinion}

After considering the parties' arguments, the New York Appellate Division, Third Department, largely affirmed the trial court judgment and held that New York's IFS law was unconstitutional. ${ }^{64}$ The majority of the Appellate Division wasn't convinced by the State's argument that the legislature's power to define what is gambling also included a power to say what isn't. ${ }^{65}$ Rather, the court held, the legislature can't just declare that DFS isn't gambling. ${ }^{66}$ That's for the courts to decide, and allowing the legislature to simply declare that a game isn't gambling would render the constitutional ban ineffectual:

allowing the Legislature unfettered discretion to determine what is not gambling would render meaningless the constitutional prohibition on "lottery or the sale of lottery tickets, pool-selling, book-making, or any other kind of gambling" (N.Y. Const, art I, $\S 9$ [1]) because this area would devolve to being governed by statutory law and not by the constitutional provision. Thus, IFS contests are not excluded from the constitutional meaning of "gambling" merely because the Legislature now says that it is so. ${ }^{67}$

The Appellate Division, thus, held that the New York Penal Law definition of what is prohibited gambling governs the scope of the constitutional ban. ${ }^{68}$ That is, the constitution prohibits any games that depend upon chance in a material degree, notwithstanding that they may also involve the players' skill. ${ }^{69}$ In so holding, the Appellate Division rejected the State's argument that the dominating element test for what is gambling should apply. ${ }^{70}$ Under the State's reasoning, a game wasn't gambling if skill predominated any element of chance, and it was gambling if the opposite was true. ${ }^{71}$ The dominating element test, the Appellate Division held, however, was fashioned by the Court of Appeals in evaluating lotteries, not gambling, and was rejected by the legislature when it defined gambling in the 1965 Penal Law implementing legislation as being based on whether the outcome of the game depends upon chance in a material degree. ${ }^{72}$ The Appellate Division, thus, held that "the Legislature's own definition of gambling, as included in the Penal Law since 1965, [w] as the appropriate definition for courts to apply when interpreting that word in the pertinent constitutional provision."

Turning to DFS, the court held that "IFS contestants pay an entry fee (something of value) in hopes of receiving a prize (also something of value) for performing well in an IFS contest." ${ }^{74}$ That satisfied two of the elements of the Penal Law definition of gambling. ${ }^{75}$ So, whether DFS is prohibited gambling was determined on whether the outcome depends upon a material degree of chance. ${ }^{76}$ And the Appellate Division held that it did. ${ }^{77}$ Accepting the parties' stipulation of facts regarding how DFS games work, the court held

although participants in IFS contests may use their skill in selecting teams, they cannot control how the athletes on their IFS teams will perform in the real-world sporting events. For example, those performances could be affected by such disparate circumstances as, among other things, player injury or illness, unexpected weather conditions, poor officiating, a selected player having a particularly bad day or an unselected player having a surprisingly good day. In other words, the skill level of an IFS contestant cannot eliminate or outweigh the material role of chance in IFS contests. ${ }^{78}$

It was as simple as that. Because DFS involves a material degree of chance, the court held, it is prohibited

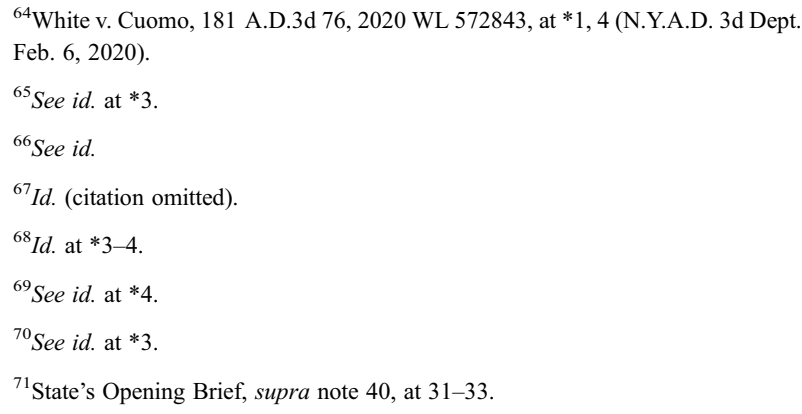

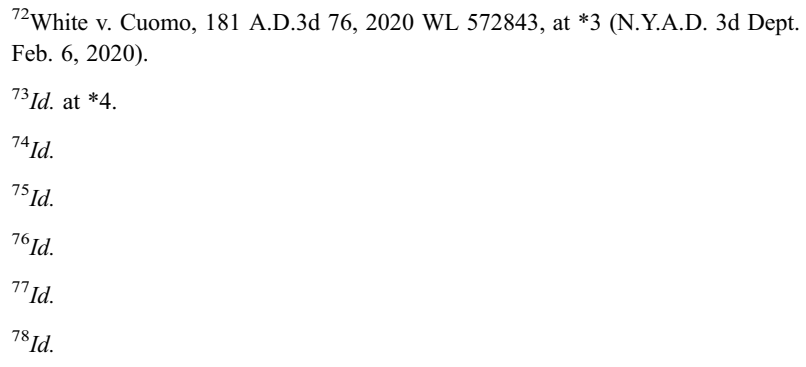

${ }^{72}$ White v. Cuomo, 181 A.D.3d 76, 2020 WL 572843, at *3 (N.Y.A.D. 3d Dept. Feb. 6, 2020).

${ }^{73} I d$. at $* 4$.

${ }^{74}$ Id.

${ }^{75} I d$.

${ }^{76} I d$.

${ }^{77} I d$.

${ }^{78} I d$. 
gambling under the constitution and cannot be authorized by mere legislation like the IFS law. ${ }^{79}$ The Appellate Division, thus, affirmed the trial court's holding that the IFS law is unconstitutional. But the majority didn't stop there. It also modified that portion of the trial court judgment that had upheld the IFS law's provisions decriminalizing DFS games. ${ }^{80}$ Although the court held that the legislature had to power to decriminalize DFS, it could not sever the provision from the rest of the IFS law and, thus, declared it unconstitutional as well. ${ }^{81}$

Justice Stan Pritzker dissented, arguing that the majority went well beyond the appropriate standard of review in this constitutional challenge to the IFS law. ${ }^{82}$ As Justice Pritzker saw it, the court's task was to limited to "deciding whether the Legislature rationally determined, after hearing and considering evidence, that IFS contests are not 'gambling' as defined under Penal Law § 225.00." "83 Because ample evidence existed in the legislative record for that determination, Justice Pritzker would have upheld the IFS law because the plaintiffs did not meet their initial burden to show that the law was unconstitutional beyond a reasonable doubt. ${ }^{84}$

Justice Pritzker reasoned,

the Legislature's judgment necessarily involved determining whether an IFS contest is a "game of chance" and, as such, analyzing whether the degree of chance is "material" in determining the outcome of an IFS contest. Because it is not seriously disputed that an IFS contest involves a high degree of skill, as was found by Supreme Court, then determining whether the degree of chance inherent in an IFS contest is "material" presented a difficult and nuanced question for the Legislature. And, although it may have been rational to determine that the amount of chance in an IFS contest is material, as did some of the legislators who voted against the bill, it was not at all unreasonable, based upon the legislative record, to conclude otherwise. The difference is that the legislation bears the imprimatur and presumption of constitutionality and, thus, summary judgment should not have been granted in favor of plaintiffs.

...

Supreme Court incorrectly focused on the fact that the participants do not have actual influence over the athletes. However, this notion was debated by the Legislature and it ultimately concluded that the proper focus is not on the participants' influence over the real world events and a specific athlete's performance, but the participants' unquestionable influence on winning the contest by making skillful choices in assembling a fantasy roster. Indeed, the plethora of evidence that was rationally relied upon by the Legislature in finding that IFS contests are predominantly contests of skill - a finding that $\mathrm{Su}-$ preme Court accepted-also supports the notion that IFS contestants meaningfully, using certain parameters such as data and salary cap management, influence the outcome of the contests. ${ }^{85}$

Thus, because the legislature rationally decided that skill predominates over chance in DFS games, Justice Pritzker would have declared that the IFS law did not violate the New York Constitution's ban on gambling. ${ }^{86}$

\section{The State's appeal as of right to the New York Court of Appeals}

Although most cases can't be appealed to the New York's highest appellate court - the Court of Appeals - without the court's permission, ${ }^{87}$ this isn't most cases. The DFS suit happens to have one of the limited jurisdictional bases that allows a party to bypass a motion for leave to appeal and take an appeal as of right to the court of appeals. Under New York's Civil Procedure Law and Rules, a party may take an appeal as of right to the Court of Appeals

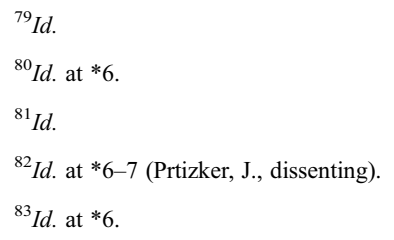

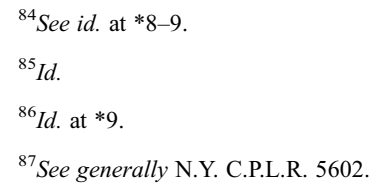


from a final Appellate Division order that directly involves a substantial constitutional question. ${ }^{88}$ Although the requirements are easy to state (the constitutional question must be (1) directly involved and (2) substantial), ${ }^{89}$ their application is much more difficult.

For a constitutional question to be directly involved, it first must have been preserved both at the trial court and at the Appellate Division. ${ }^{90}$ A constitutional issue raised only at the Appellate Division and reached as a matter of the Appellate Division's interests of justice jurisdiction is not enough. ${ }^{91}$ The constitutional question must also have been necessarily decided by the Appellate Division. ${ }^{92}$ So, if the Appellate Division decided the case on a number of independent grounds, including nonconstitutional ones, the constitutional question is not directly involved for purposes of an appeal as of right. ${ }^{93}$

What does it mean that the constitutional question is substantial? That's a case-by-case decision by the Court of Appeals. ${ }^{94}$ The question doesn't need to be a winner, but it also can't already have been decided against the appellant's position in prior precedent. ${ }^{95}$ Otherwise, the court generally looks at a number of things to determine substantiality, including "the nature of the constitutional interest at stake, the novelty of the constitutional claim, whether the argument raised may have merit, and whether a basis has been established for distinguishing a state constitutional claim (if asserted) from a federal constitutional claim." 96

In the DFS suit, satisfying the Court of Appeals' jurisdictional requirements for an appeal as of right

\footnotetext{
${ }^{88}$ See N.Y. C.P.L.R. 5601(b)(1).

${ }^{89}$ See Arthur Karger, The Powers of the New York Court of Appeals $§ 7: 2$ (3d ed. 2005) ("so long as such a constitutional question is directly involved, an appea as of right will lie even though other questions may also be involved, and all questions in the case which the Court of Appeals is empowered to review will be open for consideration, whether or not they are of a constitutional nature"); id. § 7:5 ("Another basic rule, applicable to both classes of appeals, is that the constitutional question must be a substantial one.").

${ }^{90}$ See Matter of Schulz v. State of New York, 81 N.Y.2d 336, 344 (N.Y.1983); see also Matter of Skenesborough Stone, Inc. v. Village of Whitehall, appeal dismissed 95 N.Y.2d 902 (N.Y. 2000)

${ }^{91}$ See Mingo v. Pirnie, 55 N.Y.2d 1019, 1020 (N.Y. 1982) (although the constitutional question was raised and reviewed in Appellate Division, the Court of Appeals refused to consider it because the "issue was not raised in the petition" at the trial court).

${ }^{92}$ See KARGER, supra note $89, \S 7: 8$

${ }^{93}$ See Board of Educ. of Monroe-Woodbury Cent. School Dist. v. Wieder, $72 \mathrm{~N}$ Y.2d 174, 182 (N.Y. 1988) ("Even where a constitutional question may be oth-
}

isn't an issue. The only question that the Appellate Division decided was whether the IFS law violated the constitutional ban on gambling under Article I, $\S 9$. The constitutional question was, therefore, directly involved and preserved at both the trial court and the appellate division. The question whether DFS is prohibited gambling is also an issue of first impression, the courts below certainly found merit in the plaintiffs' arguments, and New York's constitutional ban on gambling is unique from the federal constitution. This case, therefore, has a directly involved, substantial constitutional question over which the Court of Appeals may exercise jurisdiction. And because the State filed its appeal as of right quickly after the appellate division's decision, the automatic stay of enforcement, and the DFS games, will continue until after the Court of Appeals decides the issue. ${ }^{97}$

\section{NEXT UP: THE NEW YORK COURT OF APPEALS WILL DECIDE ONCE AND FOR ALL WHETHER DFS IS PROHIBITED GAMBLING}

As the case now proceeds to the New York Court of Appeals to decide whether DFS is a substantive form of gambling that is prohibited by the New York Constitution, the dispositive issues seem to be the standard of review that the court must apply, and how the court applies the statutory definition of a contest of chance.

On the first point, the Appellate Division majority and dissent sharply divided over the standard of review that applies to the plaintiffs' constitutional challenge. ${ }^{98}$ The Appellate Division majority rejected the State's assertion that deference was owed to the legislature's erwise involved, an appeal as of right does not lie if the decision appealed from was or could have been based upon some ground other than construction of the Constitution.").

${ }^{94}$ See KARGER, supra note $89, \S 7: 5$ ("Whether a particular constitutional issue is sufficiently substantial to warrant an appeal as of right is, generally speaking, rather a matter of judgment, to be determined on the facts of the individual case.").

${ }^{95}$ See id.

${ }^{96}$ The New York Court of Appeals Civil Jurisdiction and Practice Outline, at 4, available at https://www.nycourts.gov/ctapps/forms/civiloutline.pdf (last accessed Mar. 10, 2020)

${ }^{97}$ See N.Y. C.P.L.R. 5519(e) (providing that if the state files its notice of appeal within five days after the order appealed from is served with notice of its entry, the stay of enforcement automatically continues during the appeal).

${ }^{98}$ Compare White v. Cuomo, 181 A.D. $3 d$ 76, 2020 WL 572843, at *1-2 (N.Y.A.D. 3d Dept. Feb. 6, 2020) (majority discussion of standard of review) with id. at *6-7 (Pritzker, J., dissenting). 
rational fact finding, based on evidence and testimony in the legislative record, that DFS did not involve chance to a material degree and, thus, was not prohibited gambling. ${ }^{99}$ Rather, the majority concluded, that determination is left for the courts to say whether DFS fits within the definition of gambling. ${ }^{100}$ The Appellate Division dissent, on the other hand, would have applied a standard of review deferential to the legislature's conclusions, asking only whether evidence existed in the record to support its determination. ${ }^{101}$

If the Court of Appeals adopts the State's and Appellate Division dissent's suggested standard of review, the IFS law becomes much easier to defend. The legislature held hearings and took plenty of expert testimony on how the skill involved in DFS predominates over any element of chance. ${ }^{102}$ Even if the judges of the Court of Appeals would have reached a different conclusion than the legislature, ${ }^{103}$ evidence certainly exists in the record to support the legislature's findings. The State's proffered standard of review, therefore, would constrain the court to uphold the law.

If the Court of Appeals follows the standard of review set out by the Appellate Division majority, however, the case will likely turn on the court's answer to this question: what does it mean for the outcome of a game to "depend ... upon" a "material degree" of chance? ${ }^{104}$ The Appellate Division majority held that because DFS players can't control whether their chosen athletes have a bad shooting day, go 0-4 with four strikeouts, get hurt in the first quarter, or face inclement weather, the DFS games necessarily involve a material degree of chance. ${ }^{105}$ I'm not convinced that that's conclusive of the inquiry, however.

A material degree of chance cannot be found merely by reference to what happens on the field or court in real-life sports games. That distorts what DFS really is - a game unto itself where groups of contestants vie to pick the lineup that best performs on a given day in an independent virtual contest off the field. DFS is not a wager on a specific sporting contest or any particular player performance over which the contestant has no control. It's a test of the DFS player's skill in assembling the best team given the information and conditions that the he or she can glean from advanced statistics, news reports, and even the National Weather Service, and in testing that skill against the skills of the other contestants doing the same.

For example, if the contestant knows before the lineup lock deadline that the Tennessee Titans face a defense that is particularly favorable to opposing running backs but stingy against the passing game, and the game is likely to be played outdoors in high winds, the DFS player will use that information to form his or her strategy. The contestant may decide to pay up for Derrick Henry, rather than play a lowbudget stack of Ryan Tannehill and A.J. Brown. Fitting the puzzle pieces together and staying within the defined salary cap is an exercise of a DFS player's skill, especially given the vast amount of information that has to be synthesized to make informed lineup decisions. ${ }^{106}$ The chance involved that a chosen player has a bad day or faces inclement weather, however, is not an essential element of the outcome of the DFS contest itself; it is what the DFS player has to weigh in selecting a lineup in the first place.

Like a win in chess, a win in a DFS contest depends not on chance, but on the choices that the other contestants make compared to your own. ${ }^{107}$ Indeed, if you better measure the unknown variables of sport and make better predictions based on the information you have, you will win. If the other DFS contestants

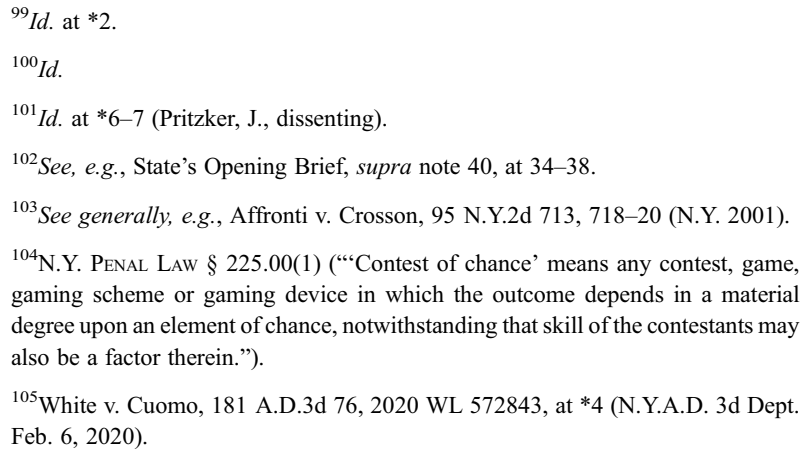

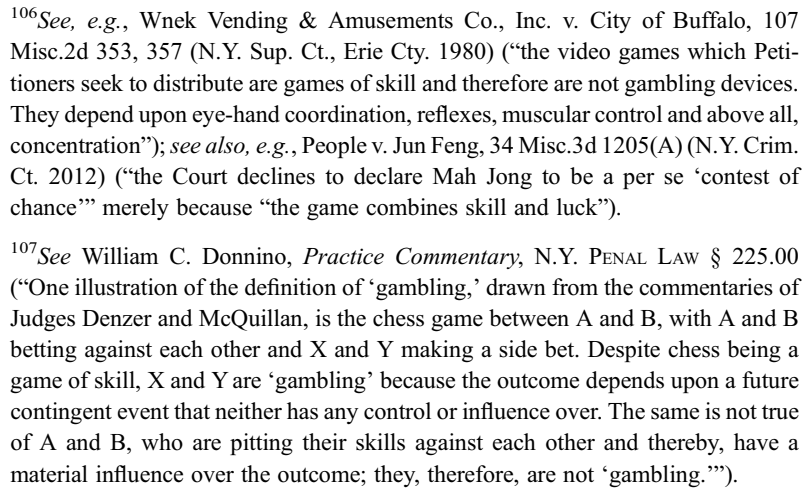

${ }^{106}$ See, e.g., Wnek Vending \& Amusements Co., Inc. v. City of Buffalo, 107 Misc.2d 353, 357 (N.Y. Sup. Ct., Erie Cty. 1980) ("the video games which Petitioners seek to distribute are games of skill and therefore are not gambling devices. They depend upon eye-hand coordination, reflexes, muscular control and above all, concentration"); see also, e.g., People v. Jun Feng, 34 Misc.3d 1205(A) (N.Y. Crim. Ct. 2012) ("the Court declines to declare Mah Jong to be a per se "contest of chance" merely because "the game combines skill and luck").

${ }^{107}$ See William C. Donnino, Practice Commentary, N.Y. Penal Law $§ 225.00$ ('One illustration of the definition of 'gambling,' drawn from the commentaries of Judges Denzer and McQuillan, is the chess game between A and B, with A and B betting against each other and $\mathrm{X}$ and $\mathrm{Y}$ making a side bet. Despite chess being a game of skill, $\mathrm{X}$ and $\mathrm{Y}$ are 'gambling' because the outcome depends upon a future contingent event that neither has any control or influence over. The same is not true of $\mathrm{A}$ and $\mathrm{B}$, who are pitting their skills against each other and thereby, have a material influence over the outcome; they, therefore, are not 'gambling."'). 
weigh all of those considerations better, then you won't. The mere fact that a little bit of luck is involved, however, does not elevate the degree of chance above the threshold for materiality.

The legislature's determination that the chance on which DFS outcomes depend does not rise to the level of a material degree is also supported by its prior classification of horseracing handicapping tournaments as outside of the definition of prohibited gambling. ${ }^{108}$ In a handicapping tournament, a participant pays an entry fee and tests his or her skill in picking winners against the other entrants in return for the chance to take home the winner's prize. The handicappers don't control how the horses they have picked run in the races, how the jockeys decide to ride the horse, or the track conditions, but the legislature nevertheless determined that the separate handicapping contest is a game of skill, not one on which the outcome depends upon a material degree of chance, and therefore is not prohibited gambling. ${ }^{109}$ So too with DFS.

Even if that analogy wasn't conclusive, ${ }^{110}$ New York courts have held how a "material degree" is determined in other contexts. For example, the New York Constitution prohibits the removal or destruction of any trees in the state's designated forest preserve. ${ }^{111}$ Although that prohibition is absolute in its language, the Court of Appeals held that it must be interpreted reasonably to permit some tree cutting, so long as it does not exceed a "substantial extent." 112 To the court, that meant that "all things necessary were permitted, such as measures to prevent forest fires, the repairs to roads and proper inspection, or the erection and maintenance of proper facilities for the use by the public which did not call for the removal of the timber to any material degree."113 Analyzing that language again just last year, the Appellate Division, Third Department, held that in determining materiality for purposes of the constitutional tree cutting prohibition, the courts could examine not only "tree size and maturity," but also the overall importance of the trees that are proposed to be cut to the forest preserve. ${ }^{114}$ The test that the New York courts have set out for materiality, therefore, requires a qualitative analysis of the activity proposed.

If a qualitative analysis of the DFS games is required under New York precedent, that analysis is best left to the legislature, not the courts. ${ }^{115}$ The legislature has the time and resources to evaluate all of the evidence, and ask for more if what they've found isn't enough to decide whether the outcome of a DFS contest depends upon chance in a material degree. ${ }^{116}$ The courts, in contrast, are constrained only to the evidence that the particular parties to a case put before them. The courts' role in evaluating the materiality of chance in the outcome of DFS games is thus best constrained to whether the legislature's analysis is supported by the evidence, while according proper deference to the decision that the elected representatives of the people of the state have made.

The legislature here undertook the necessary qualitative analysis of the proposed DFS games, called for
${ }^{108}$ N.Y. Rac. Pari-Mut. WaG. AND BREed. LaW $§ 906(3)$

${ }^{109} I d$.

${ }^{110} \mathrm{An}$ argument could be made that because the legislature's exemption of horseracing handicapping tournaments from the definition of prohibited gambling was never challenged in the courts, it does not necessarily support the conclusion that the legislature had the power to do so.

${ }^{111}$ N.Y. ConST. art. XIV, $§ 1$ ("The lands of the state, now owned or hereafter acquired, constituting the forest preserve as now fixed by law, shall be forever kept as wild forest lands. They shall not be leased, sold or exchanged, or be taken by any corporation, public or private, nor shall the timber thereon be sold, removed or destroyed.").

${ }^{112}$ Association for Protection of Adirondacks v. MacDonald, 253 N.Y. 234, 242 (N Y. 1930) (holding that removal of 2,500 trees to construct a bobsled run for the Olympics violated the State Constitution's ban on tree removal).

${ }^{113} I d$. at 238 (emphasis added).

${ }^{114}$ Protect the Adirondacks! Inc. v. New York State Dept. of Envtl. Conservation, 175 A.D.3d 24, 31 (N.Y.A.D. 3d Dept 2019), appeals pending undecided (N.Y. Ct. App); see also, e.g., Balsam Lake Anglers Club v. Dept. of Envtl. Conservation, 199 A.D.2d 852, 853-54 (N.Y.A.D. 3d Dept 1993) ("The record before us indicates that approximately 350 trees have been or will need to be cut to accommodate the trail relocation; the remaining cutting (312 saplings) concerns vegetative growth that DEC does not classify as trees. (The amount of cutting needed for the proposed new trail and parking lots has not yet been determined.) These proposed uses appear compatible with the use of forest preserve land, and the amount of cutting necessary is not constitutionally prohibited."), appeal withdrawn 83 N.Y.2d 907 (N.Y. 1994).

${ }^{115}$ See Saratoga County Chamber of Commerce, Inc. v. Pataki, 100 N.Y.2d 801, 821-22 (N.Y. 2003) ("Article III of the State Constitution vests the Senate and the Assembly with the legislative power of the State, while article IV vests the executive power in the Governor and article VI vests the court system with the judicial power. We have recognized that these separate grants of power to each of the coordinate branches of government imply that each branch is to exercise power within a given sphere of authority. Stated succinctly, the separation of powers requires that the Legislature make the critical policy decisions, while the executive branch's responsibility is to implement those policies" (citations and internal quotation marks omitted))

${ }^{116}$ See In re Joint Legislative Comm. to Investigate Educ. Sys. of State of New York, 285 N.Y. 1, $8-9$ (N.Y. 1941) ("The law-making power given to the Legislature authorizes it, by inquiry, to ascertain facts which affect public welfare and the affairs of government. Such power of inquiry, with process to enforce it, is an essential auxiliary to the legislative function. A legislative body may act upon common knowledge or information voluntarily contributed. At times it stands in need of more. There is then power to investigate by subpoena under the sanction of an oath. Upon such inquiries the Legislature may compel the attendance of witnesses and the production of documentary evidence to the end that it may perform its constitutional functions by the enactment of laws to correct public dangers either real or apprehended." (citations and internal quotation marks omitted)). 
by New York's statutory definitions and precedent, before enacting the IFS law. It created an extensive legislative record including evidence from both sides of the issue and made a decision, like it previously did with horseracing handicapping tournaments, that DFS outcomes do not depend upon chance to such a significant or essential ${ }^{117}$ degree that it is prohibited by the constitution. Because the legislature's determination is supported not only by the evidence in the legislative record, but also by a rational understanding of what DFS contests entail, the Court of Appeals should uphold the IFS law.

\section{CONCLUSION}

No question, this is a very close case that will likely divide the seven judges of the New York Court of Appeals. One way or the other, the DFS industry and players across New York will know by early 2021 if the games can continue or will have to stop while the legislature follows the two-year process neces- sary to amend the New York Constitution to expressly authorize DFS. ${ }^{118}$

The New York Court of Appeals' forthcoming decision in White v. Cuomo, however, does not stand in the way of the New York Legislature's efforts to authorize other forms of online or mobile gaming or sports betting by mere legislation. ${ }^{119}$ Because the question in this case is whether DFS is a substantive form of gambling prohibited by the constitution's express ban, the court's decision will not have any impact on the legislature's power to authorize new methods of offering sports betting or casino gaming, which have already been exempted from the constitutional ban. ${ }^{120}$ Thus, the legislature remains free to amend the casino gaming article of the Racing, Pari-Mutuel Wagering and Breeding Law to provide that casino games like poker and sports betting permitted under the 2013 amendment to the New York Constitution may be offered online and through mobile betting. ${ }^{121}$ So although DFS remains at risk, at least White v. Cuomo won't stand in the way of all online and mobile gaming in New York.
${ }^{117}$ See Material, Black's Law Dictionary (11th ed. 2019) (“Of such a nature that knowledge of the item would affect a person's decision-making; significant; essential").

${ }^{118}$ N.Y. CONST. art. XIX, $\S 1$ (an amendment to the N.Y. Constitution may only be adopted upon passage in two successive legislative sessions and a majority vote of the People of the state in a general election).

${ }^{119}$ See generally Daniel Wallach and Robert Rosborough, Let New Yorkers Bet on Games Online: Restricting Sports Betting to Upstate Casinos Would Forfeit Millions in Tax Revenue, N.Y. Post (op-ed), Feb. 22, 2019, available at http://www. nydailynews.com/opinion/ny-oped-let-new-yorkers-bet-on-games-online-

20190219-story.html (last accessed Apr. 3, 2020) ("The state Constitution only addresses substantive categories of gambling, not the delivery channels for how and where bets are placed. Once a form of gambling is authorized, the Constitution gives the Legislature power to regulate the details of wagering. That's why the constitutional provisions authorizing the state lottery, pari-mutuel betting on horse races and casino gambling include the phrase 'as may be authorized and prescribed by the legislature,' meaning that it's up to lawmakers to 'authorize and prescribe' how wagering on those constitutionally-permitted forms of gambling will work.").

${ }^{120}$ See, e.g., N.Y. RAC. PARI-Mut. WAG. AND BreED. LAW § 1012; 9 N.Y.C.R.R. § 4500.9(b) ("The account wagering licensee may accept account wagers via any wired or wireless communications device, including but not limited to wireline telephones, wireless telephones, and the internet subject to applicable laws, rules and its approved plan of operation.").

${ }^{121}$ Legislation has been introduced in the New York Legislature to authorize online and mobile betting as a new method for offering sports wagering, which is permitted under Racing, Pari-Mutuel Wagering and Breeding Law $\S 1367$. See N.Y. Senate Bill S17D/A6113, available at https://www.nysenate.gov/legislation/bills 2019/s17 (last accessed Apr. 3, 2020). Although the bill failed to gain the necessary support to pass in the 2019 legislative session, the bill was reintroduced in January 2020 and remains under consideration. See id. 